\title{
Factors Affecting Capital Structure of Go Public Manufacturing Companies in BEI (Indonesia Stock Exchange)
}

\author{
Abdillah AN*, Ikhsan S and Mutia I
}

Department of Accounting, University of Sumatera Utara, Indonesia

\begin{abstract}
This study aims to determine and analyze the effect of company's size, business risk, asset growth, and profitability on capital structure in manufacturing companies listed on the stock exchange of Indonesia year 20142016, either partially or simultaneously. In addition, this study also reviewed variables used due to differences in previous research results. The type of data used is secondary data in the form of financial statements obtained from the Indonesian Capital Market Directory 2014-2016 period. The sampling technique used cluster proportional random sampling or group sample. This method is used because listed manufacturing companies listed in Indonesia Stock Exchange are heterogeneous, sampling to represent each element listed in Indonesia Stock Exchange based on business type, so that 25 companies in this research are obtained. Variable in this research there are two that is; Independent variables include firm size, business risk, asset growth, and profitability. As for the dependent variable is the capital structure in the manufacturing company. This research is analyzed by using multiple regressions. Based on the results of the study showed that during the study period partially firm size (SIZE) have a positive and significant effect and profitability (NPM) has a negative and significant effect. While business risks (DOL) and asset growth (GROW) have no effect on capital structure. The magnitude of this effect is 0.096 or $9.7 \%$. While the rest of $90.4 \%$ influenced by other factors outside the study or outside the regression equation.
\end{abstract}

Keywords: Size; Business risk; Growth of assets; Profitability; Capital structure

\section{Introduction}

A company is usually established with several goals to be achieved. The main objective of the company is to maximize the prosperity and profitability of its shareholders [1]. One way to achieve company goals is to increase the value of the company. Another goal of the company is to earn profits from year to year to keep the company alive. As the company growing year to year, managers must be keen on the decisions that will be taken. The asset owned by the company also influences the manager's decision. The large value of total assets is more likely to have a more diversified capital source, making it less likely to go bankrupt and better able to fulfill its obligations, so large companies tend to have larger debts than small company [2].

The second factor is business risk. In company, business risk will increase if the company is using high debt. This will also increase the probability of bankruptcy. It gives the company a high risk, so that the company should use less debt to avoid the possibility of bankruptcy.

Company with high growth rates, are likely to be short of revenues to fund the high growth internally. Because of issuing a new share requires a high cost, and then the company prefers the debt as a source of financing.

Profitability shows the net result of a series of policies and decisions [1]. Companies with high return on investment use relatively small debt. This is because highly profitable companies do not need much financing with debt because most of the financing needs are sufficient to be gained through high corporate retained earnings [3].

Research on the factors that affecting capital structure in manufacturing companies has been done by many researchers. From the results of previous research there are several differences in some variables that affect the capital structure in manufacturing companies and still show the different results and even contradiction of the research results one another. In addition, there are also differences in the research result with existing theories. This is what a research gap in this research became (Table 1).

\section{Literature Review}

\section{A. Capital structure}

Modigliani and Miller [4] approach theory argues that capital structure does not directly affect the company. In this case, it has already included the tax factor. So, the value of the company with debt is higher than the value of the company without debt, the increase is due to the tax savings.

$$
\text { DAR }=\frac{\text { Total Debt }}{\text { Total Assets }}
$$

\section{B. Business risk}

Based on the definition of risk by Brigham and Houston [1], risk is defined as the probability or occurrence of some unfortunate events. Business risk is the uncertainty that companies face in running their business activities. Business risk is a risk that includes intrinsic business risk, financial leverage risk, and operating leverage risk.

In company, business risk will increase if the company is using high debt. This will also increase the probability of bankruptcy. The results prove that companies with high risk should use less debt to avoid the possibility of bankruptcy.

*Corresponding author: Abdillah AN, Department of Accounting, University of Sumatera Utara, Indonesia, Tel: +62618211638; E-mail: badinst@usu.ac.id

Received October 13, 2017; Accepted January 19, 2018; Published January 26 2018

Citation: Abdillah AN, Ikhsan S, Mutia I (2018) Factors Affecting Capital Structure of Go Public Manufacturing Companies in BEI (Indonesia Stock Exchange). Int J Account Res 6: 173. doi:10.4172/2472-114X.1000173

Copyright: (c) 2018 Abdillah AN, et al. This is an open-access article distributed under the terms of the Creative Commons Attribution License, which permits unrestricted use, distribution, and reproduction in any medium, provided the original author and source are credited. 
Citation: Abdillah AN, Ikhsan S, Mutia I (2018) Factors Affecting Capital Structure of Go Public Manufacturing Companies in BEI (Indonesia Stock Exchange). Int J Account Res 6: 173. doi:10.4172/2472-114X.1000173

Page 2 of 4

\begin{tabular}{|l|l|l|l|}
\hline Dependent Variables & Independent Variables & Influence & Previous Researchers \\
\hline Capital Structure & Firm Size & No Affects & Nuril Hidayati (2010) [7] \\
\hline & & Positive Affects & Michael Njogu Wahome, Dr. F. Memba, \\
Dr. Willy Muturi(2015) [6] & Nuril Hidayati (2010) [7] & Significant Negative Influence \\
\hline & Business Risk & Positive Affects & Nuril Hidayati (2010) \\
\hline & Growth Assets & No Affects & Positive Affects \\
\hline & Profitability & No Affects & Paidi (2004) [8] \\
\hline
\end{tabular}

Table 1: Research gaps table.

\begin{tabular}{|c|c|c|c|}
\hline Numb. & Variable & Definition \\
\hline 1. & Capital Structure $(\mathrm{Y})$ & Comparison ratio between Total debt and total assets & Measurement Scale \\
\hline 2. & Business Risk $(\mathrm{X} 1)$ & Ratio \\
\hline 3. & Company Size $(\mathrm{X} 2)$ & The Sum of Total Assets \\
\hline 4. & Growth Assets $(\mathrm{X} 3)$ & Total Change owned by the company \\
\hline 5. & Profitability $(\mathrm{X} 4)$ & Comparison ratio between Net profit and Net Sales & Ratio \\
\hline
\end{tabular}

Table 2: Table of Operational Definition and Variable Measurement Scale.

$$
\begin{aligned}
& \text { DOL }=\frac{\text { Growth of Profit Before Taxes (EBIT) }}{\text { Growth of Net Sales }} \\
& \text { While: } \\
& \text { DOL=Degree of Operating Leverage } \\
& \text { EBIT }=\text { Earnings before Interest and Taxes }
\end{aligned}
$$

\section{Company's size}

The size of the asset is the average net sales for the current year to several years [1]. Companies with larger sizes will have access to source of funding from various sources, and easier to get loans from creditors because of the company's size.

Large company's size will also have a greater probability of winning the competition in the industry, whereas small-scale firms will face more uncertainty, as smaller firms react faster to sudden changes. Therefore, enabling large companies leverage level will be greater than in small companies.

\section{Company's Size $=$ Log Total Asset}

\section{Growth assets}

Weston and Brigham [5] say that company with current asset growth rates have to rely heavily on external capital, floating costs. And also the fast growing company will issue a high cost for debt in common stock while the using debt rather than slow growing companies.

$$
\text { Growth Assets }=\frac{\text { Total Assets at } \mathrm{t} \text { period }- \text { Total Assets at } \mathrm{t}-1 \text { period }}{\text { Total Assets at } \mathrm{t}-1 \text { period }}
$$

\section{E. Profitability}

Profitability is the company's ability to make a profit. The measure of profitability in this study is using Net Profit Margin developed [1] which said that companies with high return on investment using relatively small debt. High returns allow companies to finance most of the funding needs with internally generated funds. Weston and Brigham [5] added that often the observations show that firms with high rates of return use relatively little debt. Very profitable companies basically do not need the cost of financing with debt. High corporate retained earnings are sufficient to finance most of the funding needs.

\section{Research Method}

This study is a causal research that aims to test the hypothesis and is a study that explains the phenomenon in the form of relationships between variables. In other words, the main purpose of this study is to identify the causal relationship between the various variables. This type of research belongs to a kind of quantitative historical research, where this study explains the cause or effects of past events and current phenomena or to predict future conditions (Table 2).

\section{Operational definition and measurement variable scale}

The operational definition can be defined as an operational concept where the operational definition describes the characteristics of the object into observable elements that cause the concept to be measured and operationalized into the study. In the operational definition, any concept of the variables used in the study should have a clear definition.

\section{Population and research sample}

Sampling is used to save the time and energy in analyzing the data, however the sample must be representative for the results of the analysis can be generalized [6]. The sampling method uses in this research is by cluster method of proportional random sampling or group sampling. This method is used because listed manufacturing companies listed in Indonesia Stock Exchange are heterogeneous, sampling in order to represent each element listed in Indonesia Stock Exchange based on business type. Sampling from each sector is adjusted to the ratio or number of issuers of each sector. The number of samples of each sector is obtained by the population. The population was divided by the total population multiplied by the total sample of thirty, based on the calculation will get a sample of sufficient representative of the type of business in Indonesia Stock Exchange [7].

The number of samples selected by each sector is obtained by using the formula:

$$
\frac{\text { Population of Each Sector }}{\text { Total Population }} x \text { Total Sample Selected }
$$

Based on the technique then obtained 33 companies representing each business field in the manufacturing sector. 


\section{Result}

\section{Simultaneous test (F-Test)}

To know whether there is simultaneously influence between firm size variable, business risk, assets growth, and profitability to capital structure variable at go public manufacturing company in Indonesia Stock Exchange (BEI) in 2014-2016, then conducted Test F (simultaneous test). For more details, the calculation results can be seen in the following Table 3: Source: Result of SPSS Processing, 2017.

Based on the SPSS calculation result above we can see where the value of $\mathrm{F}$ arithmetic is bigger than $\mathrm{F}$ value in $\mathrm{F}$ Table $(70,784>4,74)$ with significant level below 0,$05 ; 0,000$. Based on the decision rules in simultaneous test in regression analysis can be concluded that business risk variables (X1), company size (X2), growth assets (X3), and Profitability (X4) significantly affect variable capital structure if tested together or simultaneously.

\section{Partial Test (t-Test)}

T-test is used to know whether there are influences of each independent variable, that is SIZE, DOL, GROW, and NPM to dependent variable, that is capital structure of manufacturing company go public in BEI year 2014-2016. Decision making is based on the probability significance of $0.05(5 \%)$ :

- If the value of $\mathrm{t}$ signicance $>0.05$, then $\mathrm{H} 0$ is accepted and $\mathrm{H} 1$ is rejected. This means that an independent variable individually has no effects on the dependent variable.

- If the significance value $\mathrm{t}$ stat $<0.05$, then $\mathrm{H} 0$ is rejected and $\mathrm{H} 1$ is accepted. This means that an independent variable individually affects the dependent variable. below:

The results in the Table 4 above can be described as explanation

- SIZE variable has t count equal to 1.064 and significance value 0,004 , research result is $0,004>0,05$ it can be concluded that its variable SIZE has positive influence to capital structure of go public manufacturing company in Indonesia Stock Exchange in year 20142016.

- DOL variable has $t$ count equal to $-0,042$ and significance value 0,967 , result of research is $0.967>0.05$ it can be concluded that its DOL variable has no positive affects to capital structure of go public manufacturing company in Indonesia Stock Exchange in year 20142016.

- GROW variable has t count equal to 1.138 and significance value
0.070 , result of research obtained $0.070>0.05$ it can be concluded that GROW variable does not have positive influence to capital structure of go public manufacturing company in Indonesia Stock Exchange in year 2014-2016.

- NPM variable has t count equal to -2.712 and significance value 0,259 , result of research obtained $0.259>0.05$ it can be concluded that variable of NPM have negative and significance influence to capital structure of go public manufacturing company in Indonesia Stock Exchange in year 2014-2016.

\section{Discussion}

As can be concluded from the results of this study as follows:

- The results in this study indicate that firm size has a positive and significant effect on capital structure. Justification because companies with larger size have access to obtain sources of funding from various sources, and easier to get loan from several sources because of the company with large size have a greater probability of winning the competition in the industry, whereas small-scale company will face more uncertainty, as a smaller company react quickly to sudden changes. Therefore, enabling large companies leverage level will be greater than in small companies [8].

- This study also indicates that business risk (DOL) has no positive effect on capital structure. It can be said that business risk does not affect the capital structure. Justification in deciding the manager's capital structure less attention to business risk problems faced because there are other factors that are more influential. Indonesia's macroeconomic conditions are still revision in the period of observation 2014-2016 cause managers already known the certainty of the existence of high business risk, so the business risk variables are not too taken into account.

- The results in this study indicate that assets growth has no positive but not significant effect on capital structure. This is because the economy is not conducive to the business world so that companies difficult to obtain asset growth. In observation in period 2014-2016 not a few manufacturing companies that have decreased assets that resulted managers do not use variable growth of assets as a references to the determination of the company's capital structure.

- This study also indicates that profitability (NPM) has a negative and significant effect on capital structure. This is because the company will use more internal funds obtained from the company's profit obtained as financing rather than using funds from outside. This supports

- Pecking order theory as the basic theory of capital structure

\begin{tabular}{|c|c|c|c|c|}
\hline Model & Sum of Squares & Df & Mean Square & Sig. \\
\hline 1. Regression & 10627.736 & 4 & 2125.547 & 70.784 \\
\hline Residual & 26635.450 & 7 & 306.155 & \\
\hline Total & 37263.186 & 11 & & \\
\hline
\end{tabular}

Table 3: Simultaneous Test (ANOVAb)

\begin{tabular}{|c|c|c|c|c|c|}
\hline \multirow[t]{2}{*}{ Model } & \multicolumn{2}{|c|}{ Unstandardized Coefficients } & \multirow{2}{*}{$\begin{array}{c}\text { Standardized Coefficient's } \\
\text { Beta }\end{array}$} & \multirow[t]{2}{*}{$\mathbf{T}$} & \multirow[t]{2}{*}{ Sig. } \\
\hline & B & Std. Error & & & \\
\hline 1. (Constant) & 35.475 & 10.910 & & -.441 & 661 \\
\hline $\mathrm{DOL}$ & -.643 & .225 & -.426 & -.042 & .967 \\
\hline SIZE & .437 & .129 & .318 & 1.064 & .004 \\
\hline GROW & 1.121 & .644 & .258 & 1.138 & .070 \\
\hline NPM & -.423 & .156 & -.249 & -2.712 & .259 \\
\hline
\end{tabular}

Table 4: Partial Test (t-Test). 
Citation: Abdillah AN, Ikhsan S, Mutia I (2018) Factors Affecting Capital Structure of Go Public Manufacturing Companies in BEI (Indonesia Stock Exchange). Int J Account Res 6: 173. doi:10.4172/2472-114X.1000173

Page 4 of 4

in looking at profitability as an independent variable. Pecking order theory states that companies like internal financing (funding from the results of the company's operations in the form of retained earnings). Further, Brigham and Houston [1] say that firms with high returns on investment use relatively little debt. The high rate of return allows the company to finance most of the funding needs with internally generated funds.

\section{Conclusion}

- This study aims to examine whether the firm size, business risk, growth assets and profitability affecting the capital structure of manufacturing companies listed on the Indonesia Stock Exchange. Based on the results of the research discussed earlier, the conclusions of this study are as follows:

- Simultaneously, the results of this study indicate that firm size, business risk, growth assets, and profitability significantly influence the capital structure of manufacturing companies listed on the Indonesia Stock Exchange. With the calculation of the value of $\mathrm{F}$ of 70.784 with a significant level of 0,000 .

- Partially, the result of this research indicate that business risk and growth assets does not affect the capital structure, size positively affects capital structure and while profitability negatively affects capital structure.

- Based on the results of this study, suggestions that researchers submit to the next researcher is as follows:

- For company management, managers should pay more attention to the size of the company in making decisions about its own capital structure, because the results of this study indicate that firm size is a factor that can affect the capital structure of manufacturing companies.
- This study was conducted using data from 2014-2016, so that for other years or subsequent years the results of this study still needed to be tested its validity.

- For further research can be done by adding other variables such as independent variables and compare the capital structure between manufacturing and non-manufacturing companies, so it can be known further whether there are differences and the results could be more objective.

\section{References}

1. Brigham EF, Houston JF (2006) Financial Management. Jakarta; Salemba Empat.

2. Rajan, Raghuram G, Luigi Zingales (1995) what do we know about capita structure? Some evidence from International data, Journal of Finance 50: 1421-1460.

3. Weston J, Fred (1996) Financial Management. Vol. 2: (8 $8^{\text {th }}$ edn.), Jakarta Binarupa.

4. Modigliani F, Miller MH (1958) the cost of capital, Corporation Finance and the theory of investment. The American Economic Review 48: 261-297.

5. Weston FJ, Brigham EF (1991) Dasar-Dasar Manajemen Keuangan Diterjemahkan oleh: Khalid, Edisi Ketujuh, Jilid 2, Jakarta; Erlangga.

6. Wahome MN, Memba F, Muturi W (2015) The Effects of firm size and risk on Capital Structure decisions of Insurance Industry in Kenya, International Journal of Scientific and Research Publications 5: 1-12.

7. Nuril Hidayati (2010) Pengaruh Struktur Kepemilikan, Profitabilitas, Ukuran Perusahaan, Pertumbuhan Aktiva dan Resiko Bisnis terhadap struktur Moda pada Perusahaan yang masuk dala kelompok Jakarta Islamic Indeks Masa tahun 2005-2007. Student Paper UIN Sunan Kalijaga.

8. Saidi (2004) Faktor-faktor yang mempengaruhi Struktur Modal pada perusahaan Manufaktur Go Public di BEJ 1997-2002. Jurnal Bisnis dan Ekonomi 11: 44-58 